\title{
STRATEGI MENINGKATKAN KUALITAS OLAH BAHASA UNTUK CERITA PENDEK SISWA SEKOLAH DASAR DENGAN PENDEKATAN GENRE-BASED
}

\author{
Djatmika, Fitria Akhmerti Primasita, Agus Dwi Priyanto
}

\author{
Email: djatmika@uns.ac.id \\ Jurusan Bahasa dan Sastra Inggris Fakultas Sastra dan Seni Rupa UNS \\ Alamat Koresponden: Jalan Ir. Sutami 36A Surakarta
}

\begin{abstract}
Indonesian elementary school students show their motivation to write. A kind of books written by and for children of their age, commonly termed as Kecil-Kecil Punya Karya (KKPK) 'although young we have writing works', are nowdays available at bookstores. These books can further motivate other children to compose. To accommodate this motivation, the language center of Sebelas Maret University of Surakarta held a writing contest for elementary school students in Surakarta and the surrounding area. Thirtyfour students participated the contest, thus 34 texts from such a competition were collected as the object of analysis in this study to see the quality of the text structure as well as the text texture of the texts. The analysis on the text structure shows that several texts are arranged in a single kind of genre. However, the other texts are composed in multi-genre-meaning that each text in this kind demonstrates the features of a genre, but it accomodates other short texts with different genre. The former is named as a text with a macro genre, whereas the latter are termed as texts with a micro one. Meanwhile, the choice of words and the exploitatio of grammatical construction for the clauses of most of the texts shows weaknesses. Many academic and technical terms as well as nominalization are exploited. In addition, several texts have metaphorical words in them. This phenomenon influences the readability level of the texts. Furthermore, many clauses are constructed in complex arrangement, while some otheSrs incomplete in terms of grammar substances. This, therefore, add the negative quality of the texts. Several systemic strategies are provided to make the texts better. They can be effective models for the young writers as well as for the teachers of Bahasa Indonesia subject at elementary schools.
\end{abstract}

\section{Keywords}

Genre, Cerita, Gramatika, Teks

\section{Pendahuluan}

Pada saat sekarang banyak buku cerita dengan berbagai jenis yang ditulis untuk pembaca sasaran anak Indonesia. Selain untuk menyediakan media hiburan bagi para pembaca anak-anak, buku-buku tersebut diharapkan dapat menjadi materi penunjang proses tumbuh kembang mereka baik yang berkaitan dengan perkembangan kognitif, perkembangan emosi, atau perkembangan bahasa mereka. Khusus untuk perkembangan bahasa, kebiasaan membaca buku cerita memang diyakini memberikan pengaruh positif kepada para pembaca anak tersebut. Salah satu fenomena yang merepresentasikan hubungan positif ini adalah semakin banyaknya buku-buku cerita anak yang ditulis oleh penulis anak, misalnya seri buku KecilKecil Punya Karya (KKPK).

Kehadiran buku-buku cerita sejenis ini memberikan sebuah rangsangan bagi banyak siswa sekolah dasar untuk mencoba menuangkan ide cerita mereka dalam sebuah karangan. Hal ini didukung oleh kurikulum yang mendasari mata pelajaran bahasa Indonesia di sekolah mereka. Kurikulum yang berlaku pada saat ini dirancang secara genre-based dengan membekali para anak didik dengan keterampilan menggunakan bahasa secara fungsional.

Namun demikian, kurikulum yang bersifat genrebased dan ditambah dengan proses belajar mengajar yang mendukung kurikulum tersebut kurang maksimal di dalam membekali anak didik 
dengan keterampilan menggunakan bahasa Indonesia. Bahkan, sebagian guru yang harus mentransfer materi ajar yang bersifat genre-based tersebut kurang maksimal dalam hal penguasaan materi maupun dalam penyampaian. Hal ini sebagian terlihat dari hasil penelitian Riyadi Santosa dan kawan-kawan (2006) yang menyimpulkan bahwa banyak guru taman kanakkanak yang kurang terampil dalam melakukan kegiatan bercerita. Sementara itu, dalam kaitan dengan buku materi, banyak buku cerita anak tulisan penulis dewasa yang menunjukkan kelemahan dalam hal olah bahasa.

Kenyataan di atas tentu saja sangat berpengaruh kepada proses pemerolehan keterampilan menggunakan bahasa bagi para anak didik. Oleh karena itu, pembahasan ini terfokus pada kualitas keterampilan olah bahasa yang dimiliki para siswa sekolah dasar dalam hal mengarang. Kelemahan dan permasalahan yang ditemukan dalam teks tulisan mereka menjadi dasar untuk menyajikan strategi sistemik yang lebih efektif untuk kegiatan menulis. 


\section{Penutup}

Hasil analisis sistemik berkaitan dengan oleh struktur dan tekstur teks karangan para penulis pemula di dalam penelitian ini menunjukkan beberapa permasalahan sebagai berikut.

a) Berkaitan dengan struktur teks, permasalahan yang muncul adalah genre ganda yang dimiliki oleh beberapa teks. Fenomena itu menjadikan teks yang bersangkutan memiliki genre makro dan genre mikro. Format bingkai-membingkai seperti ini terkesan membuat organisasi teks tersebut terkesan 'kacau'

b) Terdapat beragam kesalahan tata gramatika lain yang harus direvisi untuk dapat memaksimalkan pengiriman pesan melalui konstruksi gramatika yang dibuat.

c) Pemilihan leksis/ kosa kata dan ekspresi untuk sebagian besar teks tulisan para penulis muda itu dinilai akademis dan teknis. Selain itu, banyak bentuk nominalisasi dan bentuk metaforis yang digunakan. Eksploitasi seperti ini dinilai tidak sesuai dengan usia para pembaca anak dan jenjang keterampilan berbahasa Indonesia mereka.

Sementara itu, proses validasi kualitas dan wawancara yang dilakukan kepada responden pembaca sasaran anak-anak menunjukkan bahwa olah struktur teks, pemilihan leksikon dan olah tata gramatika dari sebagian besar tulisan para siswa sekolah dasar tersebut membuat teks tulisan mereka menjadi sulit untuk dipahami. Sebagian besar para responden ternyata tidak mampu menceritakan kembali isi teks yang telah mereka baca. Sebagian yang lain tidak mampu secara utuh, dan hanya tiga responden yang mampu menceritakan kembali teks yang telah mereka baca.

Berdasarkan temuan di atas, maka beberapa saran disajikan sebagai berikut.

a) Para penulis perlu diberi pelatihan untuk melakukan pemilihan leksikon yang sesuai dengan usia dan jenjang keterampilan berbahasa Indonesia baik untuk diri penulis maupun untuk para pembaca sasaran anakanak.

b) Para guru sekolah dasar seharusnya memahami konsep genre dan olah leksikogramatika yang digunakan sebagai dasar kurikulum mata pelajaran bahasa secara nasional.

Kurikulum pengajaran bahasa Indonesia yang sudah berbasis genre seharusnya diterapkan dengan benar, sehingga keterampilan olah leksikogramatika para siswa sekolah dasar bisa ditransferkan secara maksimal kepada para penulis pemula...

\section{DAFTAR PUSTAKA}

Cartledge, G. dan Kiarie, M.W. 2001. Learning Social Skills through Literature for Children and Adolescents. In Teaching Exceptional Children, Vol. 34, No.2, pp. 40-47.

Eggins, S. 1994. An Introduction to Systemic Functional Linguistics. London: Pinter Publishers.

Gerrot, L. dan Wignell, P. 1995. Making Sense of Functional Grammar. Cammeray: AEE.

Halliday, M.A.K. 1994. An Introduction to Functional Grammar. London: Edward Arnold.

Halliday, M.A.K. dan Hasan, R. 1985. Language, Context and Text: Aspects of Language in A Social Semiotic Perspective. Victoria: Deakin University.

Martin, J.R. 1992. English Text: System and Structure. Philadelpia: John Benjamins Publishing Company

Martin, J.R. dan Rose, David. 2004. Working with Discourse. London: Continuum.

Riyadi, Santosa, Djatmika, dan Fitria A.P. 2006. Sastra Anak Sebagai Wahana Pengenalan Dan Pengasuhan Ideologi: Sebuah Kajian Wacana. Jurnal Penelitian Humaniora, Juni 2006 